\title{
Variability of nutrients and carbon dioxide in the Antarctic Intermediate Water between 1990 and 2014
}

\author{
Essowè Panassa ${ }^{1}$ (ID . J. Magdalena Santana-Casiano ${ }^{2}$. Melchor González-Dávila ${ }^{2}$. Mario Hoppema ${ }^{1}$. \\ Steven M.A.C van Heuven ${ }^{3}$. Christoph Völker ${ }^{1}$. Dieter Wolf-Gladrow ${ }^{1}$. Judith Hauck ${ }^{1}$
}

Received: 12 August 2017 / Accepted: 4 January 2018 / Published online: 9 February 2018

(C) The Author(s) 2018. This article is an open access publication

\begin{abstract}
Antarctic Intermediate Water (AAIW) formation constitutes an important mechanism for the export of macronutrients out of the Southern Ocean that fuels primary production in low latitudes. We used quality-controlled gridded data from five hydrographic cruises between 1990 and 2014 to examine decadal variability in nutrients and dissolved inorganic carbon (DIC) in the AAIW (neutral density range $27<\gamma_{n}<27.4$ ) along the Prime Meridian. Significant positive trends were found in DIC $\left(0.70 \pm 0.4 \mu \mathrm{mol} \mathrm{kg}-1\right.$ year $\left.^{-1}\right)$ and nitrate $\left(0.08 \pm 0.06 \mu \mathrm{mol} \mathrm{kg}^{-1}\right.$ year $\left.^{-1}\right)$ along with decreasing trends in temperature $\left(-0.015 \pm 0.01{ }^{\circ} \mathrm{C}_{\text {year }}{ }^{-1}\right)$ and salinity $\left(-0.003 \pm 0.002\right.$ year $\left.^{-1}\right)$ in the AAIW. Accompanying this is an increase in apparent oxygen utilization (AOU, $0.16 \pm 0.07 \mu \mathrm{mol} \mathrm{kg}^{-1}$ year ${ }^{-1}$ ). We estimated that $75 \%$ of the DIC change has an anthropogenic origin. The remainder of the trends support a scenario of a strengthening of the upper-ocean overturning circulation in the Atlantic sector of the Southern Ocean in response to the positive trend in the Southern Annular Mode. A decrease in net primary productivity (more nutrients unutilized) in the source waters of the AAIW could have contributed as well but cannot fully explain all observed changes.
\end{abstract}

Keywords Prime Meridian · Antarctic Intermediate Water · Carbon · Nutrients · Decadal variability

\section{Introduction}

The Southern Ocean (SO) is a key ocean region of the global carbon cycle. Outgassing of $\mathrm{CO}_{2}$ driven by the upwelling of carbon-rich deep water (Hoppema 2004b) is counteracted by $\mathrm{CO}_{2}$ draw-down by biological production and by uptake of anthropogenic $\mathrm{CO}_{2}$ (Metzl et al. 2006; Gruber et al. 2009). The global ocean takes up 30\% of the anthropogenic carbon that is released to the atmosphere (Le Quéré et al. 2016). Of those $30 \%$, the SO takes up about $40 \%$, i.e., $12 \%$

Responsible Editor: Emil Vassilev Stanev

Electronic supplementary material The online version of this article (https://doi.org/10.1007/s10236-018-1131-2) contains supplementary material, which is available to authorized users

Essowè Panassa essowe.panassa@awi.de

Extended author information available on the last page of the article. of total anthropogenic $\mathrm{CO}_{2}$ emissions (Sabine et al. 2004; Khatiwala et al. 2009). A reduction in the SO uptake of anthropogenic $\mathrm{CO}_{2}$ in the 1990s was suggested by Wetzel et al. (2005) and Le Quéré et al. (2007) based on ocean and atmosphere inverse models and observations of atmospheric $\mathrm{CO}_{2}$. The observations were explained by the increase in the westerlies in response to the positive trend in the Southern Annular Mode, leading to more upwelling (Thompson et al. 2011; Marshall 2003). However, in the 2000s, the SO carbon sink has regained its strength (Landschützer et al. 2015). The reinvigoration of the SO carbon sink was suggested to be linked to the weakening of the upper-ocean overturning circulation as revealed by global inverse model analysis (DeVries et al. 2017).

The SO is also the largest high-nitrate low-chlorophyll (HNLC) region. The macronutrients nitrate and phosphate are not utilized completely by the phytoplankton because of iron (Martin et al. 1990; De Baar et al. 1990) and light limitation (Mitchell et al. 1991; Nelson and Smith 1991). These macronutrients are supplied from below by large-scale upwelling. The unused nutrients are advected further north 
by Ekman transport. Surface waters which are still rich in nitrate and phosphate are subducted between the Antarctic Polar Front (APF) and the Subantarctic Front (SAF), forming Antarctic Intermediate Water (AAIW) and Subantarctic Mode Water (SAMW, Gordon 1981; Peterson and Whitworth 1989; Talley 1996; Hanawa and Talley 2001). The formation and ventilation of SAMW and AAIW in the SO are crucial for the exchange of water mass properties between high and low latitudes (Rintoul et al. 2001; Talley 2013; Gordon 1981; de las Heras and Schlitzer 1999). The export of nutrients through this pathway may be responsible for the nutrient supply that fuels up to three quarters of the biological export production in the global ocean north of $30^{\circ} \mathrm{S}$ (Marinov et al. 2006; Sarmiento et al. 2004).

The Atlantic sector of the SO is one of the primary conduits through which high latitude surface, thermocline, and intermediate waters are advected equatorward and further to cold northern Atlantic regions (de las Heras and Schlitzer 1999). The northward transport of surface and intermediate waters in the Atlantic sector of the SO compensates the southward flow of North Atlantic Deep Water (NADW) and Circumpolar Deep Water (CDW) and forms part of the global Meridional Overturning Circulation (Bryden et al. 2005; Wunsch and Heimbach 2006; de las Heras and Schlitzer 1999). The Upper Circumpolar Deep Water (UCDW) upwells in the Antarctic Divergence zone between 55 and $65^{\circ} \mathrm{S}$ and is characterized by high concentrations of $\mathrm{CO}_{2}$ and nutrients (Fig. 1; Whitworth and Nowlin 1987). The northward Ekman transport of the resulting surface waters across the Antarctic Circumpolar Current (ACC) reaches its maximum value at about $50^{\circ} \mathrm{S}$ between the Antarctic Polar Front (APF) and the Subantarctic Front (SAF) (Morrison et al. 2015). Here, subduction leads to the formation of the Antarctic Intermediate Water (AAIW, neutral density of $27<\gamma_{n}<$ 27.4; Sloyan and Rintoul 2001, Fig. 2). The Subantarctic Mode Water (SAMW, 26.0 $<\gamma_{n}<26.8$; Sloyan and Rintoul 2001) is produced north of the SAF (Hanawa and Talley 2001). In deeper layers, North Atlantic Deep Water (NADW), a high-saline and low-nutrient water mass flows southward, feeding into the CDW.

South of the Antarctic divergence, Antarctic Surface Water (AASW) flows toward the Antarctic continent where it cools and becomes saltier as a result of brine rejection during sea-ice formation. This loss of buoyancy leads to a sinking of water to the bottom layer where it is known as Weddell Sea Bottom Water (WSBW). Weddell Sea Deep Water (WSDW) is formed partly by sinking of dense shelf waters that mixed with Warm Deep Water (WDW) to intermediate depth and partly by mixing of WSBW with overlying water masses (Rintoul et al. 2001). WSDW is light enough to leave the Weddell Sea and is then spread in the

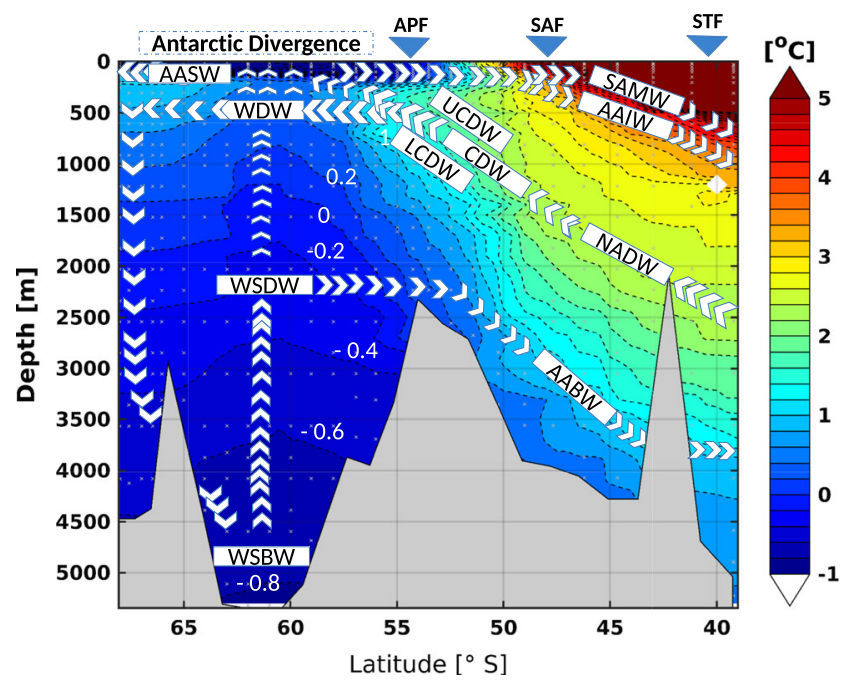

Fig. 1 Section of potential temperature of the cruise ANT-XXX/2 (2014). On the top, we show the schematic representation of the circulation of the water masses along the Prime Meridian south of the Subtropical Front (STF) located at about $40^{\circ} \mathrm{S}$, modified from van Heuven et al. (2011). AAIW = Antarctic Intermediate Water; AASW = Antarctic Surface Water; NADW = North Atlantic Deep Water; $\mathrm{CDW}=$ Circumpolar Deep Water; UCDW = Upper Circumpolar Deep Water; LCDW = Lower Circumpolar Deep Water; WDW = Warm Deep Water; WSDW $=$ Weddell Sea Deep Water; WSBW $=$ Weddell Sea Bottom Water; and AABW = Antarctic Bottom Water. The blue triangles represent the mean positions of the Antarctic Polar Front (APF), Subantarctic Front (SAF), and STF

world oceans as Antarctic Bottom Water (AABW, Orsi et al. 1999).

Recently, a speed-up in the transport of surface and intermediate waters in the Atlantic sector of the SO was reported based on the observations of transient tracers, leading to more sequestration of anthropogenic carbon dioxide in this water mass (Tanhua et al. 2017). Salt et al. (2015) reported rapid acidification of the AAIW in the southwest Atlantic. More to the south in the Weddell Gyre, nutrient concentrations significantly increased in the surface and bottom layers from 1996 to 2011 (Hoppema et al. 2015). Also, in the same region along the Prime Meridian, van Heuven et al. $(2011,2014)$ found that dissolved inorganic carbon (DIC) concentrations significantly increased in the bottom water. This suggests that gradual changes are occurring in the nutrient and carbon concentrations in the Atlantic sector of the SO. An investigation on how nutrients and total carbon dioxide concentrations have changed in the Antarctic Intermediate Water along the Prime Meridian is, however, lacking.

The objective of this study is to investigate the interannual variability of nutrients and dissolved inorganic carbon (DIC) in the AAIW in the Atlantic sector of the SO. We additionally use hydrographic and oxygen data between 1990 and 2014 along the Prime Meridian north of the APF 

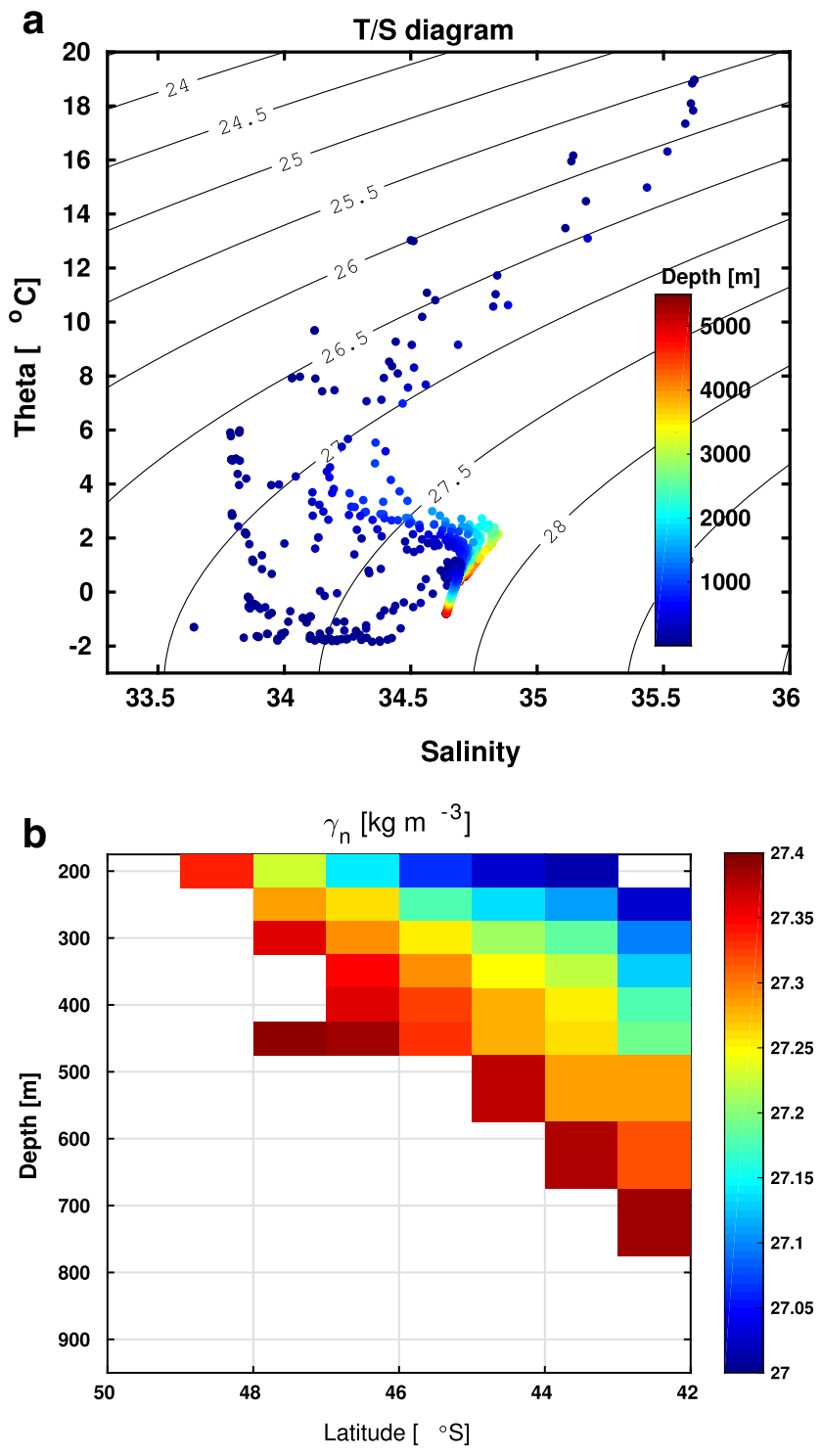

Fig. 2 a Temperature-salinity (T/S) diagram of niskin bottle data and b section plot of neutral density of the cruise 2014 (ANT-XXX/2). AAIW is located within the neutral density range of $27<\gamma_{n}<27.4$ (Sloyan and Rintoul 2001)

for supporting our case. Possible mechanisms that drive the observed variability of nutrients and DIC in relation to the circulation in the Atlantic sector of the SO are discussed.

\section{Methods and data}

Data are presented from a new cruise in 2014 (Boebel 2015) which has not been published previously. In addition, we extracted relevant hydrographic and biogeochemical data from cruises that covered our area of investigation (Prime Meridian north of the APF) from the global ocean data analysis project version 2 (GLODAPv2) database (Olsen et al. 2016), an internally consistent data product for the world ocean. We extracted 10 cruises from GLODAPv2 that sampled our area of interest and from these we selected the cruises that met all of the following criteria: (i) sufficient spatial resolution in the region north of the APF between 50 and $42^{\circ} \mathrm{S}$, the latitude range along which the intermediate and mode waters are formed (Hanawa and Talley 2001), (ii) acceptable quality of the carbon dioxide, and chemical data (WOCE flag $=2$, Olsen et al. 2016), (iii) cruises also sampled the region between $57^{\circ} \mathrm{S}$ and $66^{\circ} \mathrm{S}$ that is used for checking the consistency of the datasets (explained below).

Four cruises from GLODAPv2 met these criteria so in total we analyzed the datasets from five cruises that cover the years 1990, 1992, 1998, 2008, and 2014 (Table 1, Fig. 3). Four cruises (1992, 1998, 2008, and 2014) are from the German icebreaker FS Polarstern. The 1990 expedition was conducted on board FS Meteor. The cruise from 1992 did not sample dissolved oxygen data north of $50^{\circ} \mathrm{S}$. The new data from the cruise in 2014 (ANT-XXX/2, expocode 06AQ20141202; 2 December 2014 to 1 February 2015) is presented in this study (Section 3.1). The hydrographic data of this cruise appear in Driemel et al. (2017).

The data collected by the five cruises used in this study encompass potential temperature $(\theta)$, salinity $(\mathrm{S})$, macronutrients (nitrate $\mathrm{NO}_{3}^{-}$, phosphate $\mathrm{PO}_{4}^{3-}$ and silicic acid $\left.\mathrm{H}_{4} \mathrm{SiO}_{4}\right)$, total alkalinity $\left(\mathrm{A}_{T}\right)$, directly measured dissolved inorganic carbon (DIC) (as opposed to calculated from secondary variables), and dissolved oxygen $\left(\mathrm{O}_{2}\right)$. For the 2014 cruise (Boebel 2015), measurements of the dissolved nutrients, $\mathrm{NO}_{3}^{-}, \mathrm{PO}_{4}^{3-}$, and $\mathrm{H}_{4} \mathrm{SiO}_{4}$ were performed by UV-Vis spectrophotometric methods (Grasshoff et al. 1983) carried out on board with a Seal Analytical continuous-flow AutoAnalyzer. The concentration of dissolved oxygen in each sample collected by Niskin bottles at the Rosette sampler, mounted around the conductivity-temperature depth (CTD) sensor, was analyzed using a potentiometric Winkler method (Carpenter 1965). A VINDTA 3C system (Mintrop et al. 2000) was used for the determination of both $A_{T}$ by acid potentiometric titration and DIC by coulometry after phosphoric acid addition, with a precision of \pm 2 and \pm $1 \mu \mathrm{mol} \mathrm{kg}{ }^{-1}$, respectively. From 1998 onwards, Certified Reference Material (CRM) was used for all $\mathrm{CO}_{2}$ analyses (Dickson 2010).

We checked the consistency of the cruise ANT-XXX/2 (2014) data against adjusted GLODAPv2 cruises in the range of the lower Warm Deep Water and upper Weddell Sea Deep Water (IWDW/uWSDW) between the latitudes of $57-66^{\circ} \mathrm{S}$ and $800-2200 \mathrm{~m}$ depth for all eleven cruises that cover this region. This water mass is considered the least ventilated in the wider region (Klatt et al. 2002). For this purpose, we used all GLODAPv2 cruises that fulfilled the selection criteria (ii) and (iii) from above, i.e., cruises that cover the region chosen for the quality control with 

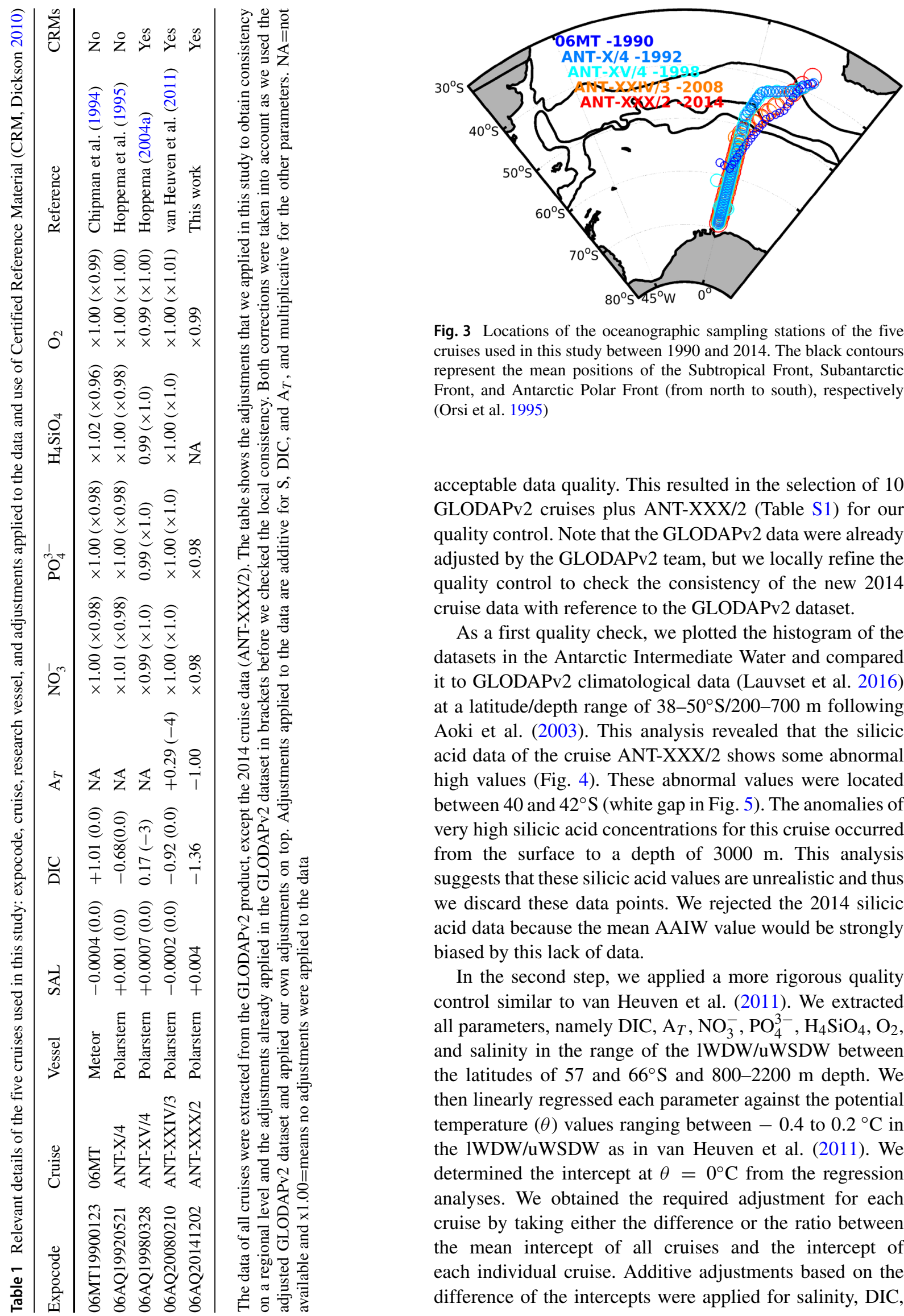

Fig. 3 Locations of the oceanographic sampling stations of the five cruises used in this study between 1990 and 2014. The black contours represent the mean positions of the Subtropical Front, Subantarctic Front, and Antarctic Polar Front (from north to south), respectively (Orsi et al. 1995)

acceptable data quality. This resulted in the selection of 10 GLODAPv2 cruises plus ANT-XXX/2 (Table S1) for our quality control. Note that the GLODAPv2 data were already adjusted by the GLODAPv2 team, but we locally refine the quality control to check the consistency of the new 2014 cruise data with reference to the GLODAPv2 dataset.

As a first quality check, we plotted the histogram of the datasets in the Antarctic Intermediate Water and compared it to GLODAPv2 climatological data (Lauvset et al. 2016) at a latitude/depth range of $38-50^{\circ} \mathrm{S} / 200-700 \mathrm{~m}$ following Aoki et al. (2003). This analysis revealed that the silicic acid data of the cruise ANT-XXX/2 shows some abnormal high values (Fig. 4). These abnormal values were located between 40 and $42^{\circ} \mathrm{S}$ (white gap in Fig. 5). The anomalies of very high silicic acid concentrations for this cruise occurred from the surface to a depth of $3000 \mathrm{~m}$. This analysis suggests that these silicic acid values are unrealistic and thus we discard these data points. We rejected the 2014 silicic acid data because the mean AAIW value would be strongly biased by this lack of data.

In the second step, we applied a more rigorous quality control similar to van Heuven et al. (2011). We extracted all parameters, namely DIC, $\mathrm{A}_{T}, \mathrm{NO}_{3}^{-}, \mathrm{PO}_{4}^{3-}, \mathrm{H}_{4} \mathrm{SiO}_{4}, \mathrm{O}_{2}$, and salinity in the range of the IWDW/uWSDW between the latitudes of 57 and $66^{\circ} \mathrm{S}$ and 800-2200 m depth. We then linearly regressed each parameter against the potential temperature $(\theta)$ values ranging between -0.4 to $0.2{ }^{\circ} \mathrm{C}$ in the IWDW/uWSDW as in van Heuven et al. (2011). We determined the intercept at $\theta=0^{\circ} \mathrm{C}$ from the regression analyses. We obtained the required adjustment for each cruise by taking either the difference or the ratio between the mean intercept of all cruises and the intercept of each individual cruise. Additive adjustments based on the difference of the intercepts were applied for salinity, DIC, 

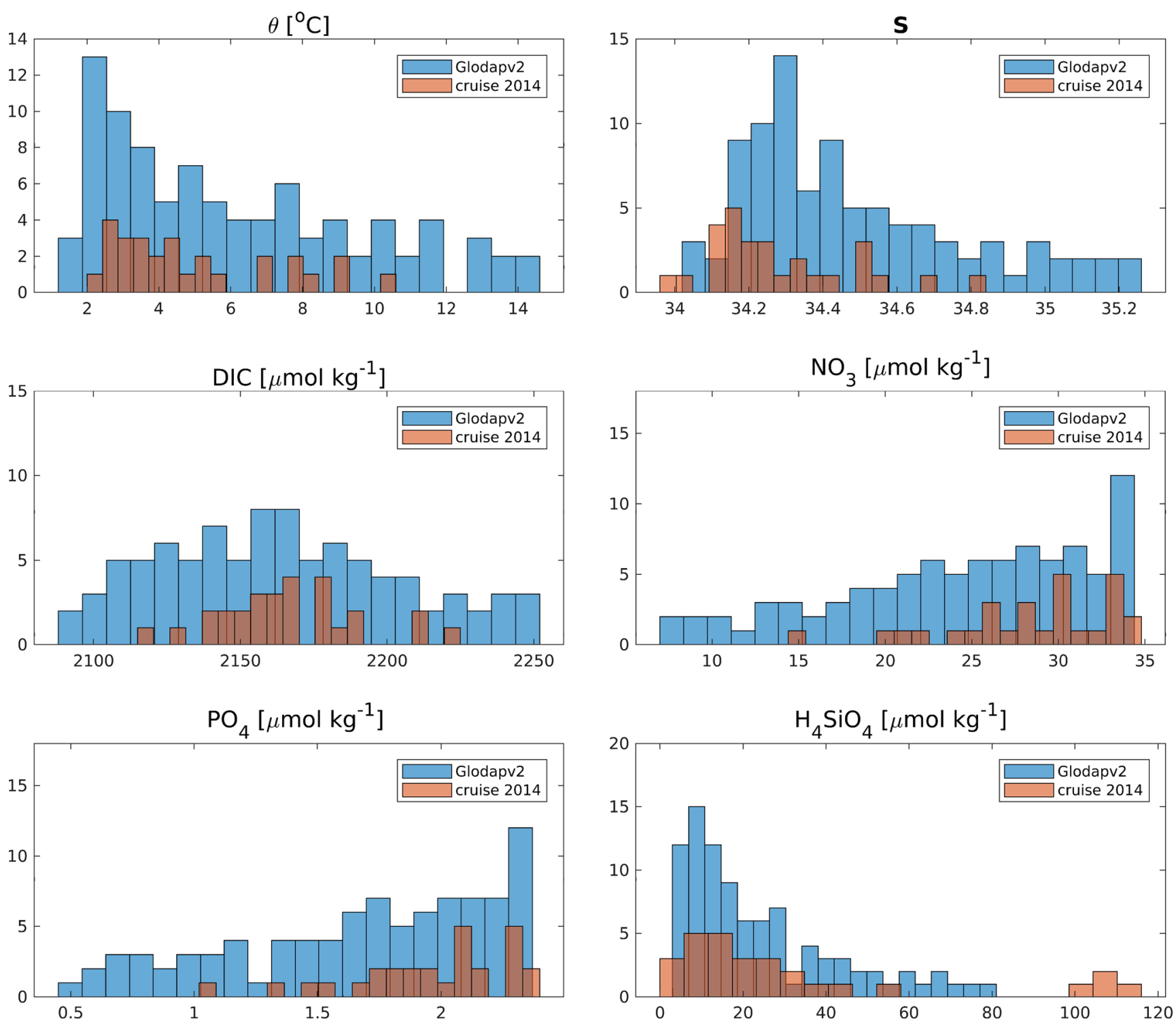

Fig. 4 Histogram showing the frequency distribution of observed values. The $y$-axis shows the number of observations between 200 and $700 \mathrm{~m}$ of the AAIW of a certain range of values as given on the $x$-axis.

and $\mathrm{A}_{T}$, and multiplicative adjustments based on the ratio were applied for nutrients and $\mathrm{O}_{2}$ prior to further analyses to have optimal consistency among all cruises (van Heuven et al. 2011). The data from all 11 cruises showed consistent relationships with $\theta$ for all biogeochemical parameters selected within the IWDW/uWSDW water mass. Only the adjustments of the five selected cruises for the AAIW analysis are shown in this study (Table 1).

In general, we found and applied small adjustments that are in most cases below the minimum adjustment limits defined by GLODAPv2 ( 0.005 for salinity, $2 \%$ for nutrients, $4 \mu \mathrm{mol} \mathrm{kg}^{-1}$ for DIC and $6 \mu \mathrm{mol} \mathrm{kg}{ }^{-1}$ for $\mathrm{A}_{T}$ and $1 \%$ for oxygen, Olsen et al. 2016). This confirms the high-quality

of the global GLODAPv2 quality control and applying these adjustments assures consistency of our dataset also on a regional level.

We then interpolated all cruise data onto a common grid assuming the longitude of all data is $0^{\circ} \mathrm{E}$. For the gridding, we use a spacing of $0.5^{\circ}$ in latitude and we use 46 vertical layers with $50 \mathrm{~m}$ thickness from the surface to $500 \mathrm{~m}, 100 \mathrm{~m}$ from 600 to $1500 \mathrm{~m}$, and $200 \mathrm{~m}$ thickness from 1700 to the bottom. We assumed that the bottom topography is the same for all cruises.

For the gridding of the datasets, we used the simple objective mapping interpolation method as did van Heuven et al. (2011). The advantage of this method is that it 
Fig. 5 Sections $(0-1500 \mathrm{~m})$ along the Prime Meridian from Polarstern ANT-XXX/2: neutral density $\left(\gamma_{n}\right)$, salinity $(\mathrm{S})$, potential temperature $(\theta)$, dissolved inorganic carbon (DIC), total alkalinity $\left(\mathrm{A}_{T}\right)$, nitrate $\left(\mathrm{NO}_{3}^{-}\right)$, phosphate $\left(\mathrm{PO}_{4}^{3-}\right)$, silicic acid $\left(\mathrm{H}_{4} \mathrm{SiO}_{4}\right)$, and apparent oxygen utilization (AOU). Gray dots indicate sampling stations. The deep sections (1501 $\mathrm{m}$ to bottom) are shown in Fig. S2

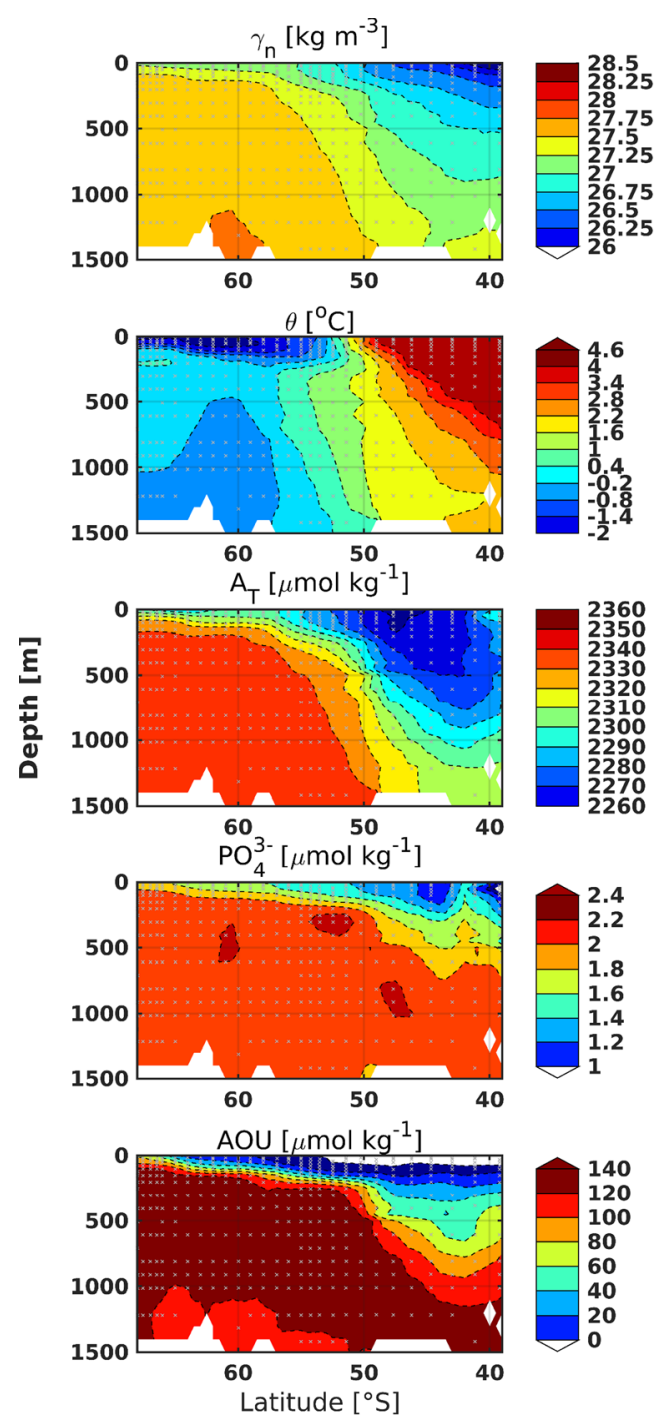

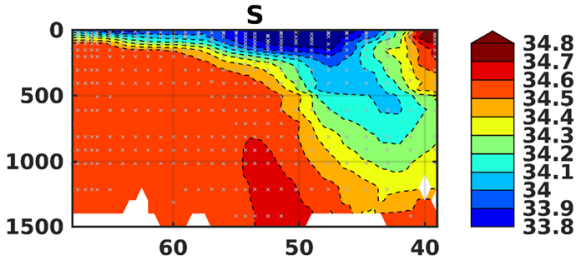
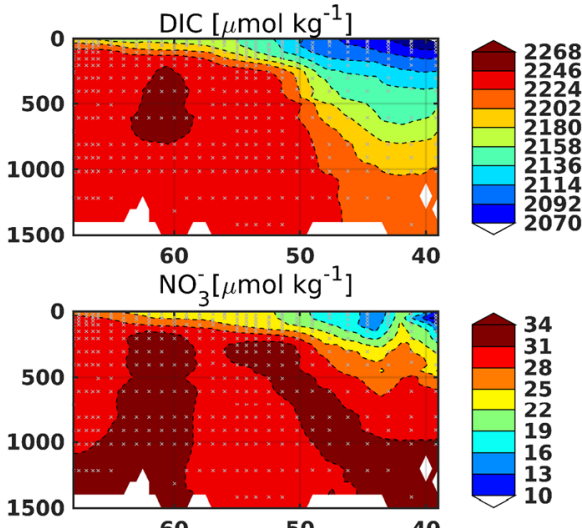

$\mathrm{H}_{4} \mathrm{SiO}_{4}\left[\mu \mathrm{mol} \mathrm{kg}^{-1}\right]$

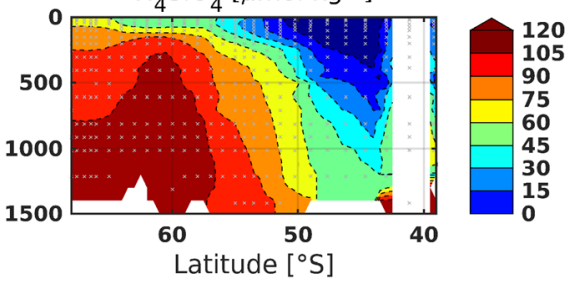

assigns equal weight to all cruises by resampling all data of interest onto a common grid. This avoids the overrepresentation of those cruises that have more observations. The core routine is the "obana.m" function, which does the actual gridding and is part of the datafun toolbox available on http://mooring.ucsd.edu/software/matlab/doc/ toolbox/datafun/index.html.

The apparent oxygen utilization (AOU) was calculated from dissolved oxygen, temperature, and salinity using the constants of Weiss (1970). Using the quality-controlled, gridded data, we evaluated the decadal variability of $\theta$, salinity, nutrients, DIC, and AOU in the AAIW, which is here defined by the neutral density range of $27<\gamma_{n}<27.4$ (Sloyan and Rintoul 2001) and latitude/depth range of 42$50^{\circ} \mathrm{S} / 200-700 \mathrm{~m}$ (Fig. 2). We limit our analysis to the depth at $700 \mathrm{~m}$ which is the lower limit of AAIW in most years (Fig. S1).
The mean and standard deviation of each variable was calculated for the whole water mass in all years. A time trend analysis was performed of the cruise mean values using the ordinary linear least squares fit. In addition, we measured inter-annual variability by the inter-annual range (IAR) that we define as follows:

$\mathrm{IAR}=\max \left(\left|\overline{\overline{\mathrm{X}}}-\overline{\mathrm{X}}_{k}\right|\right)$,

where $\overline{\mathrm{X}}_{k}$ is the mean of each cruise specified by the index $k$ and $\overline{\bar{X}}$ is the overall mean of all cruises. This measure is similar to the standard deviation in the sense that the standard deviation calculates the mean of all differences between the overall mean and the mean of each individual cruise $\left(\mathrm{STD}=\right.$ mean $\left.\left(\left|\overline{\overline{\mathrm{X}}}-\overline{\mathrm{X}}_{k}\right|\right)\right)$ whereas the IAR calculates the maximum of these differences. We prefer the IAR over the STD as the STD tends to underestimate the deviation from the mean if the data is not normally distributed. 


\section{Results}

\subsection{Sections of the cruise ANT-XXX/2 (2014)}

The distributions of nitrate, phosphate, silicic acid, $\mathrm{A}_{T}$, DIC, salinity, potential temperature $(\theta)$, apparent oxygen utilization (AOU) and neutral density $\left(\gamma_{n}\right)$ along the Prime Meridian section for the cruise ANT-XXX/2 (2014) are shown in Fig. 5.

In the region north of $50^{\circ} \mathrm{S}$, silicic acid shows a very strong vertical gradient with near-surface values below 1.5 $\mu \mathrm{mol} \mathrm{kg}{ }^{-1}$ to values of $130 \mu \mathrm{mol} \mathrm{kg}-1$ at $4000 \mathrm{~m}$ (Fig. 5 and Fig. S2). $\mathrm{NO}_{3}^{-}, \mathrm{PO}_{4}^{3-}$, DIC, and $\mathrm{AOU}$ show low values at the surface $\left(\mathrm{NO}_{3}^{-}<10 \mu \mathrm{mol} \mathrm{kg}{ }^{-1}, \mathrm{PO}_{4}^{3-}<0.75 \mu \mathrm{mol}\right.$ $\mathrm{kg}^{-1}$, DIC $<2066 \mu \mathrm{mol} \mathrm{kg}-1$, AOU $<100 \mu \mathrm{mol} \mathrm{kg}{ }^{-1}$ ) and in the inflowing North Atlantic Deep water $\left(\mathrm{NO}_{3}^{-}<\right.$ $26 \mu \mathrm{mol} \mathrm{kg}{ }^{-1}, \mathrm{PO}_{4}^{3-}<1.8 \mu \mathrm{mol} \mathrm{kg}{ }^{-1}$, DIC $<2200 \mu \mathrm{mol}$ $\mathrm{kg}^{-1}$, AOU $<110 \mu \mathrm{mol} \mathrm{kg}-1$ ). High concentrations of nitrate, phosphate, DIC, and AOU are found in the UCDW between 1100 and $1200 \mathrm{~m}\left(\mathrm{NO}_{3}^{-}>34 \mu \mathrm{mol} \mathrm{kg}{ }^{-1}\right.$, $\mathrm{PO}_{4}^{3-}>2.4 \mu \mathrm{mol} \mathrm{kg}{ }^{-1}$, DIC $>2272.5 \mu \mathrm{mol} \mathrm{kg}{ }^{-1}, \mathrm{AOU}>$ $140 \mu \mathrm{mol} \mathrm{kg}^{-1}$ ).

South of $50^{\circ} \mathrm{S}$, nutrients, AOU, DIC, and $\mathrm{A}_{T}$ show minima at the surface, maxima beneath it, and then they decrease monotonically toward the bottom. However, the values are higher and more homogeneous than those north of $50^{\circ} \mathrm{S}$ for the same depths (Fig. S2, Hoppema et al. 1998, Weiss et al. 1979). The distributions of density, salinity, potential temperature, nutrients, AOU, alkalinity, and DIC of the cruise ANT-XXX/2 comply with the hydrographic features observed during previous cruises (Fig. S3 to S6).

\subsection{Carbon and nutrient variability in the AAIW along the Prime Meridian}

We analyzed the time series of the overall water mass properties in the AAIW (neutral density range of $27<\gamma_{n}<$ 27.4) with respect to inter-annual variability (Figs. 6 and 7). Application of a linear regression to the cruise mean values yielded significant negative trends (level of significance $\alpha=0.05$ ) for $\theta$ and salinity, and significant positive trends for DIC, $\mathrm{NO}_{3}^{-}$, and AOU.

We found significant linear increases of $7 \pm 4 \mu \mathrm{mol} \mathrm{kg}^{-1}$ decade $^{-1}$ for DIC and $0.8 \pm 0.6 \mu \mathrm{mol} \mathrm{kg}{ }^{-1}$ decade $^{-1}$ for $\mathrm{NO}_{3}^{-}$(Fig. 7). The AOU increased over time (1.6 \pm $0.7 \mu \mathrm{mol} \mathrm{kg}{ }^{-1}$ decade $^{-1}$, Fig. 7) in line with the increase of macronutrients. In contrast, we found significant negative trends of $-0.16 \pm 0.1^{\circ} \mathrm{C}$ decade $^{-1}$ for $\theta$ and $-0.03 \pm$ 0.02 decade $^{-1}$ for salinity (Fig. 6). The linear trend of phosphate is not significant but it is interesting to note that the maximum and minimum concentration for each cruise are monotonically increasing with the exception of the 1998

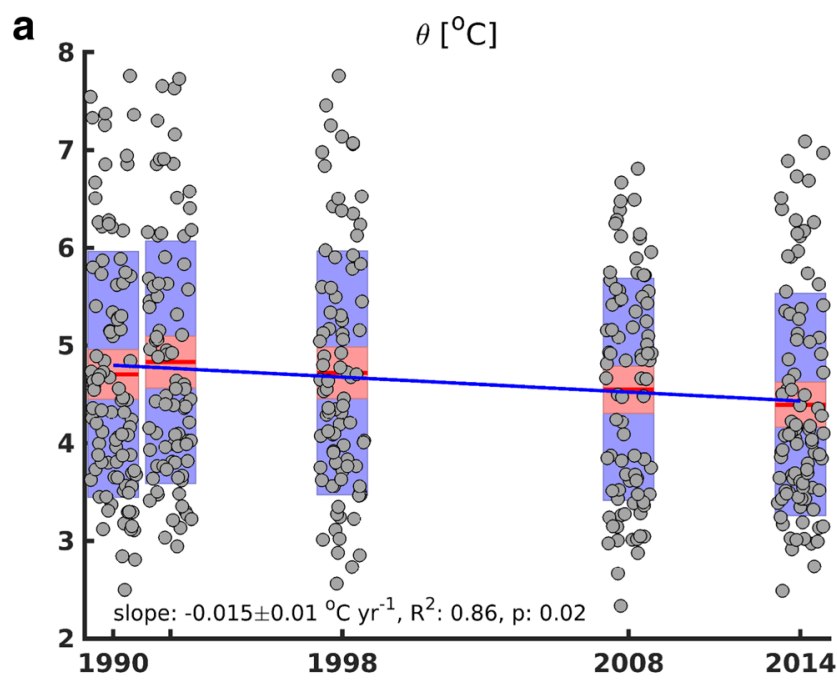

b

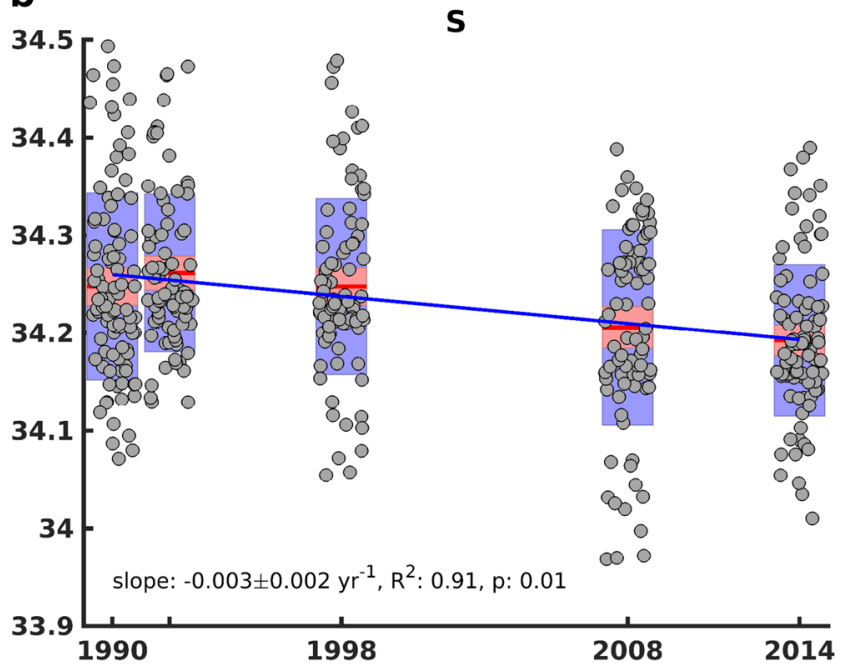

Fig. 6 Time series from 1990 to 2014 of gridded a potential temperature $(\theta)$ and $\mathbf{b}$ salinity (S) data in the core of AAIW here defined by the neutral density range $27<\gamma_{n}<27.4$ (Sloyan and Rintoul 2001). The red horizontal line represents the mean for each cruise. The light red bar represents the $95 \%$ confidence interval for the mean. The violet color indicates plus/minus one standard deviation. Non-overlapping confidence intervals indicate significant differences between means at the $5 \%$ level of significance. The raw data are shown as gray circles, with random horizontal dispersion introduced to improve the visibility of the data points. Time trends have been estimated by linear regression of cruise mean values against time. The significant trends are indicated by blue solid lines. The slope and $p$ value shown in the figure are for the trend which is calculated from the five average values of the individual cruises

data. The same is true for nitrate which in addition shows a linear positive trend of the means.

We also conducted this analysis along the density ranges of 27-27.1, 27.1-27.2, 27.2-27.3, and 27.3-27.4 (Fig. S7 to 10 , respectively). In general, $\mathrm{DIC}, \mathrm{NO}_{3}^{-}, \theta$, and $\mathrm{S}$ change consistently in the different neutral density ranges (Fig. S7 

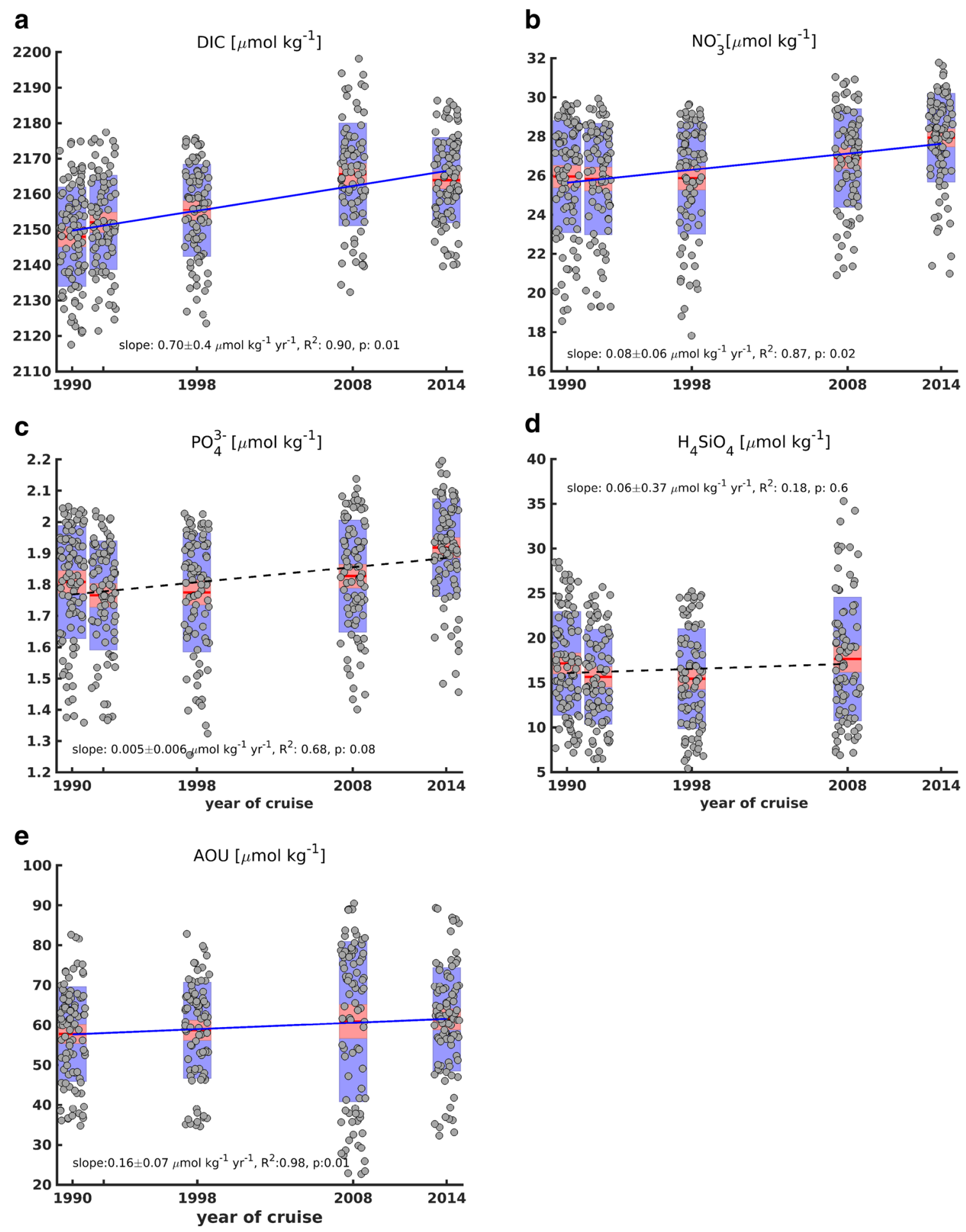

Fig. 7 Time series from 1990 to 2014 of gridded a dissolved inorganic carbon (DIC), b nitrate $\left(\mathrm{NO}^{3-}\right)$, c phosphate $\left(\mathrm{PO}_{4}{ }^{3-}\right)$ and $\mathbf{d}$ silicic acid $\left(\mathrm{H}_{4} \mathrm{SiO}_{4}\right)$ and e Apparent Oxygen Utilization (AOU) data in the core of AAIW here defined by the neutral density range $27<\gamma_{n}<27.4$ (Sloyan and Rintoul 2001). The red horizontal line represents the mean for each cruise. The light red bar represents the $95 \%$ confidence interval for the mean. The violet color indicates plus/minus one standard deviation. Non-overlapping confidence intervals indicate significant differences between means at the $5 \%$ level of significance. The raw

data are shown as gray circles, with random horizontal dispersion introduced to improve the visibility of the data points. Time trends $\left(\mu \mathrm{mol} \mathrm{kg}{ }^{-1}\right.$ year ${ }^{-1}$ ) of $\mathrm{DIC}, \mathrm{NO}_{3}^{-}, \mathrm{PO}_{4}^{3-}, \mathrm{H}_{4} \mathrm{SiO}_{4}$, and $\mathrm{AOU}$ have been estimated by linear regression of cruise mean values against time. The significant trends are indicated by blue solid lines and the dashed black lines represent statistically insignificant trends. The slope and $p$ value shown in the figure are for the trend which is calculated from the five average values of the individual cruises 
to 10). The largest changes occurred in the $\gamma_{n}$ interval of 27-27.1 (Fig. S7).

The overall mean of the potential temperature $\overline{\bar{\theta}}$ was $4.76^{\circ} \mathrm{C}$, with an IAR of $0.19^{\circ} \mathrm{C}$. The overall mean of salinity $\overline{\bar{S}}$ was 34.25 , with an IAR of 0.03 . The overall mean of dissolved inorganic carbon concentration, $\overline{\overline{\mathrm{DIC}}}$, was $2157.1 \mu \mathrm{mol} \mathrm{kg}{ }^{-1}$, with an IAR of $10.4 \mu \mathrm{mol} \mathrm{kg} \mathrm{kg}^{-1}$.

The overall mean of nitrate concentration, $\overline{\overline{\mathrm{NO}_{3}^{-}}}$, was $26.5 \mu \mathrm{mol} \mathrm{kg}{ }^{-1}$, with an IAR of $1.6 \mu \mathrm{mol} \mathrm{kg}{ }^{-1}$, equal to about $6 \%$ of the overall mean. $\mathrm{PO}_{4}^{3-}$ varied similarly, with an IAR of $0.12 \mu \mathrm{mol} \mathrm{kg}-1$, equal to about $6.6 \%$ of the overall mean of $1.82 \mu \mathrm{mol} \mathrm{kg}^{-1}$. The correlation coefficient between $\overline{\mathrm{NO}_{3}^{-}}$and $\overline{\mathrm{PO}_{4}^{3-}}$ is 0.92 , suggesting that $\mathrm{NO}_{3}^{-}$and $\mathrm{PO}_{4}^{3-}$ varied together with a mean molar ratio of 16:1. We found that the overall mean of AOU concentration, $\overline{\overline{\mathrm{AOU}}}$, was $59.72 \mu \mathrm{mol} \mathrm{kg}^{-1}$, with an IAR of $1.7 \mu \mathrm{mol} \mathrm{kg}^{-1}$.

$\mathrm{H}_{4} \mathrm{SiO}_{4}$ showed larger inter-annual variability. The overall mean of silicic acid concentration, $\overline{\overline{\mathrm{H}_{4} \mathrm{SiO}_{4}}}$, was $17.4 \mu \mathrm{mol} \mathrm{kg}^{-1}$, with an IAR of $1.9 \mu \mathrm{mol} \mathrm{kg}-1$, equal to about $11 \%$ of the overall mean. The IAR of $\mathrm{H}_{4} \mathrm{SiO}_{4}$ is based on only four cruises $(1990,1992,1998$, and 2008).

Of all years, the lowest concentrations of $\mathrm{NO}_{3}^{-}$ $\left(<18 \mu \mathrm{mol} \quad \mathrm{kg}^{-1}\right), \quad \mathrm{PO}_{4}^{3-} \quad\left(<1.4 \quad \mu \mathrm{mol} \quad \mathrm{kg}^{-1}\right)$, and $\mathrm{H}_{4} \mathrm{SiO}_{4}\left(<6 \mu \mathrm{mol} \mathrm{kg}{ }^{-1}\right)$ were observed during the year 1998.

\section{Discussion}

We analyzed the inter-annual variability of nutrients, DIC, AOU, temperature, and salinity in the AAIW of the Atlantic sector of the SO, north of $50^{\circ} \mathrm{S}$ along the Prime Meridian. The principal findings are (i) significant positive trends of DIC, $\mathrm{NO}_{3}^{-}$, and $\mathrm{AOU}$ and negative trends of salinity and temperature in the AAIW and (ii) strong inter-annual variability of $\mathrm{H}_{4} \mathrm{SiO}_{4}$.

Substantial changes in nutrients, DIC, and AOU were also observed in other sectors of the SO (Iida et al. 2013; Ayers and Strutton 2013; Pardo et al. 2017) and in the subtropical Indian Ocean (Álvarez et al. 2011). Our estimates of IAR of nutrients are lower than the standard deviations of nutrients for another mode water mass (Subantarctic Mode Water, SAMW) in the Pacific and Australian sectors of the SO (Ayers and Strutton 2013). This suggests that either the variability is lower for Atlantic AAIW than for Pacific and Australian SAMW or that these differences arise due to differences in spatial and temporal data coverage.

Based on our results, $\overline{\text { DIC }}$ concentrations in the AAIW increased at a rate of $0.70 \pm 0.4 \mu \mathrm{mol} \mathrm{kg} \mathrm{mear}^{-1}$ $\left(\Delta \mathrm{DIC}_{\text {observed }}=17.5 \pm 10 \mu \mathrm{mol} \mathrm{kg} \mathrm{kg}^{-1}\right.$ in 25 years $)$ and
$\overline{\mathrm{NO}_{3}^{-}}$increased at a rate of $0.08 \pm 0.06 \mu \mathrm{mol} \mathrm{kg}^{-1}$ year $^{-1}$ $\left(2 \pm 1.5 \mu \mathrm{mol} \mathrm{kg}^{-1}\right.$ in 25 years).

We estimated the theoretical DIC increase solely caused by the atmospheric $\mathrm{CO}_{2}$ increase in the source water of the AAIW that we define as $50-53^{\circ} \mathrm{S} / 0-100 \mathrm{~m}$. The atmospheric $\mathrm{CO}_{2}$ increase of $44.75 \mathrm{ppm}$ between 1990 and 2014 at a given Revelle factor of 14.2 in 1990 would result in a theoretical $\Delta$ DIC $_{a n t}$ of $19 \mu \mathrm{mol} \mathrm{kg}^{-1}$ in this area. This is an upper estimate for anthropogenic carbon in the AAIW as time has passed since the AAIW has last been in contact with the atmosphere. Note that the mean DIC concentration in the source region $\left(50-53^{\circ} \mathrm{S} / 0\right.$ $100 \mathrm{~m}$ ) was $2134 \mu \mathrm{mol} \mathrm{kg}{ }^{-1}$ in 1990 and $2156 \mu \mathrm{mol} \mathrm{kg}-1$ in 2014 , i.e., it has actually increased by $22 \mu \mathrm{mol} \mathrm{kg}-1$ according to our observations. This finding together with the significant increase in $\mathrm{NO}_{3}^{-}$suggests that other mechanisms are involved as well. The DIC increase might be the result of positive and negative contributions to the change that partly compensate each other.

As a second approach to separate the anthropogenic carbon from other effects, we estimated the expected overall mean natural carbon change consistent with the change in $\overline{\mathrm{NO}_{3}^{-}}$concentration based on the Redfield ratios of $\mathrm{C}: \mathrm{N}: \mathrm{P}$ $=106: 14: 1$ for the Atlantic sector of the SO north of the APF (De Baar et al. 1997), which are slightly different from the classical ratios (Redfield 1963). An increase in $\overline{\mathrm{NO}_{3}^{-}}$ at a rate of $0.08 \pm 0.06 \mu \mathrm{mol} \mathrm{kg} \mathrm{kg}^{-1}$ year ${ }^{-1}$ would result in an increase in DIC of $0.61 \pm 0.45 \mu \mathrm{mol} \mathrm{kg}{ }^{-1}$ year $^{-1}$ $\left(\Delta \mathrm{DIC}_{\text {Redfield }}=15.3 \pm 11.3 \mu \mathrm{mol} \mathrm{kg} \mathrm{kg}^{-1}\right.$ in 25 years $) . \mathrm{We}$, therefore, consider two possible scenarios to explain the change in DIC based on the best estimate of $\triangle D C_{\text {Redfield }}$ $\left(15.3 \mu \mathrm{mol} \mathrm{kg}^{-1}\right)$ and on the lower estimate of $\Delta \mathrm{DIC}_{\text {Redfield }}$ (4 $\mu \mathrm{mol} \mathrm{kg}^{-1}$ ) within the $\Delta \mathrm{DIC}_{\text {Redfield }}$ uncertainty.

In the first scenario $\left(\Delta \mathrm{DIC}\right.$ Redfield $\left.=15.3 \mu \mathrm{mol} \mathrm{kg}^{-1}\right)$, the difference of $2.2 \mu \mathrm{mol} \mathrm{kg}{ }^{-1}$ between $\Delta \mathrm{DIC}_{\text {observed }}$ and $\triangle D I_{\text {Redfield }}$ represents the anthropogenic carbon that was taken up from the atmosphere and transported into the AAIW. This means that approximately $85 \%$ of the change in DIC observed could be explained by circulation or primary production changes and $15 \%$ by the uptake of anthropogenic carbon.

In the second scenario $\left(\Delta \mathrm{DIC} \mathrm{C}_{\text {Redfield }}=4 \mu \mathrm{mol} \mathrm{kg}^{-1}\right)$, the difference between $\Delta \mathrm{DIC}_{\text {observed }}$ and $\Delta \mathrm{DIC}_{\text {Redfield }}$ of $13.5 \mu \mathrm{mol} \mathrm{kg}^{-1}$ represents the anthropogenic carbon. In that case, approximately $25 \%$ of the change in DIC observed could be explained by circulation or primary production changes and $75 \%$ by the uptake of anthropogenic carbon.

Our theoretical estimate of $\Delta \mathrm{DIC}_{\text {ant }}$ of $19 \mu \mathrm{mol} \mathrm{kg}-1$ based on the atmospheric $\mathrm{CO}_{2}$ increase suggests that the true $\Delta \mathrm{DIC}$ Redfield is likely at the lower end of the range. Also, we found that the amplitude of DIC change that varies spatially between 0.2 and $1.2 \mu \mathrm{mol} \mathrm{kg}{ }^{-1}$ year $^{-1}$ 
between 44 and $50^{\circ} \mathrm{S}$ in the period 1990 to 2012 (Fig. S11) compares well with the amplitude of anthropogenic carbon change $\left(0.4-1.2 \mu \mathrm{mol} \mathrm{kg}^{-1}\right.$ year $\left.^{-1}\right)$ estimated by Tanhua et al. (2017). All these observations suggest that the more probable scenario is the one where $75 \%$ of the DIC change are explained by anthropogenic carbon uptake.

We consider two possible mechanisms that could explain the observed trends and variability of nutrients and the nonanthropogenic part of DIC (25\%) in the AAIW: (1) an increase in upwelling, northward transport, and subduction rate and (2) a change in biological uptake of nutrients in the source waters of the AAIW and in organic matter remineralization.

A schematic representation of the proposed mechanisms that could explain the changes in nutrients and DIC concentration in the AAIW is displayed in Fig. 8.

(1) Increase in upwelling, northward transport, and subduction rate:

The non-anthropogenic part of the DIC increase as well as the nitrate increase in the AAIW could be related to the positive trend in the Southern Annular Mode (SAM) since the 1990s (Thompson et al. 2011) characterized by a southward shift and intensification of subpolar westerly winds. The strengthening of winds leads to stronger upwelling of carbon dioxide and nutrient-rich Upper Circumpolar Deep Water (UCDW) (Whitworth and Nowlin 1987) and subsequently to enhanced northward Ekman transport and subduction of AAIW (Downes et al. 2011). Enhanced upwelling of carbon is directly linked to stronger transport of carbon into the ocean interior north of the Antarctic Polar Front (Hauck et al. 2013).

The hypothesis of an increase in upwelling is supported by the decrease in potential temperature $(-0.15$ $\pm 0.1^{\circ} \mathrm{C}$ decade $^{-1}$ ) that could be related to the increase in the subduction rate (Downes et al. 2011). This is in line with the findings of Tanhua et al. (2017) who reported a speed-up of ventilation in the upper intermediate waters of the Atlantic sector of the SO between 1998 and 2012 based on the analysis of transient tracers $\left(\mathrm{SF}_{6} / \mathrm{CFC}-12\right)$. The increase of nitrate due to stronger upwelling of nutrient-rich deep water is in accord with Hoppema et al. (2015) who reported an increase in nutrient concentration in the surface waters of the Weddell Sea between 1996 and 2011 and linked the changes observed in nutrients to the increase in upwelling. Also, Pardo et al. (2017) conclude that biogeochemical change in the Southern Ocean south of Tasmania between 1995 and 2011 supports a scenario of intensification of upwelling caused by an increase in westerly winds. The increase in AOU could also be in line with the hypothesis of increased upwelling (Pardo et al. 2017) based on the assumption that the low-oxygen upwelled water does not fully equilibrate with the atmosphere before being subducted as AAIW. But this scenario is at odds with a slowdown of the overturning circulation that was suggested by DeVries et al. (2017). The freshening $\left(-0.03 \pm 0.02\right.$ decade $^{-1}$ change in salinity) can be explained by the increase in net precipitation in the subpolar regions of the Southern Hemisphere (Skliris et al. 2014; Durack and Wijffels 2010).

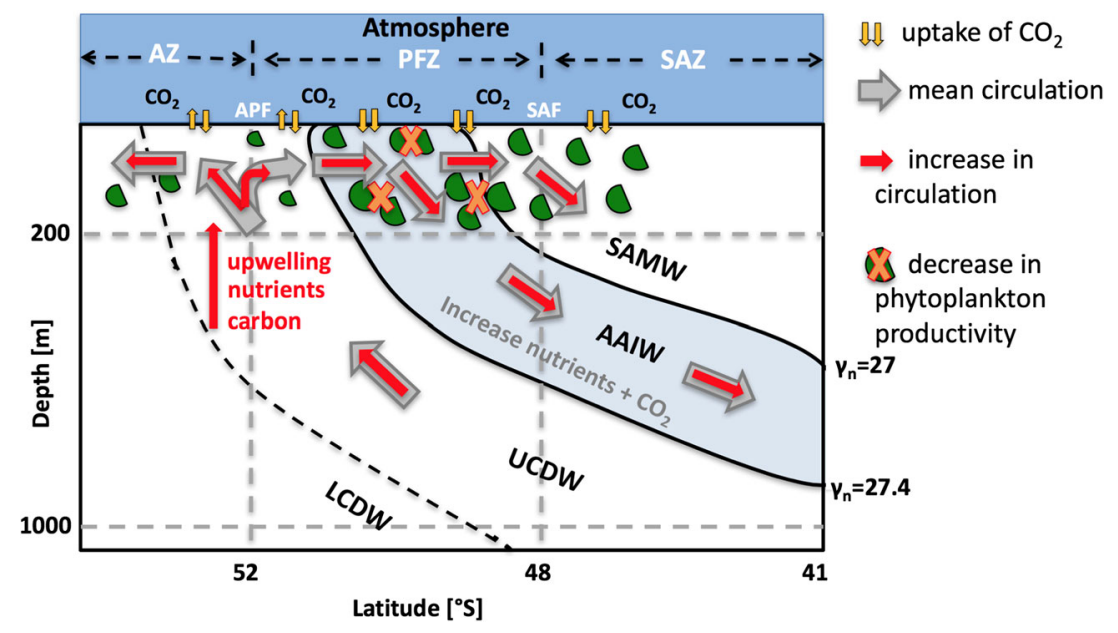

Fig. 8 Schematic representation of the proposed mechanisms that could explain the changes in nutrients and DIC concentration in the AAIW (neutral density range of $27<\gamma_{n}<27.4$ ). Gray arrows represent the mean state of the upper-ocean overturning circulation. The smaller and red arrows represent the first hypothesis: an increase in the upper-ocean overturning circulation The orange crosses represent the second hypothesis: a decrease in phytoplankton productivity. AZ = Antarctic Zone; PFZ = Polar Frontal Zone; SAZ = Subantarctic Zone; APF = Antarctic Polar Front; and SAF = Subantarctic Front. AAIW = Antarctic Intermediate Water; SAMW = Subantarctic Mode Water; UCDW = Upper Circompolar Deep Water; and LCDW $=$ Lower Circompolar Deep Water 
(2) Change in biological uptake of nutrients in the source waters of the AAIW and in organic matter remineralization:

Decreasing productivity in the source region of the AAIW may well explain the increasing nutrient concentrations observed in the AAIW core.

An increase in nitrate concentration in the AAIW could be caused by an increase in remineralization of particulate or dissolved organic carbon or could as well be caused by the decrease in nitrate uptake by phytoplankton in the surface source water of the AAIW. In the first case, larger remineralization would imply more oxygen consumption, which can be measured by apparent oxygen utilization (AOU). Indeed, we found that AOU showed a significant positive trend along with nutrients (Fig. 7).

The time trends of $\mathrm{C}: \mathrm{N}: \mathrm{P}(140: 16: 1)$ are approximately in line with the Redfield ratios. The time trend of AOU:C (1:4.4) is much smaller than expected from stoichiometric ratios (1:1.5, Anderson and Sarmiento 1994). Changes in remineralization would more lead to changes in AOU following known stoichiometry (Redfield 1963; Anderson and Sarmiento 1994). Changes in surface productivity might not necessarily lead to accompanying change in oxygen due to air-sea exchange. This suggests that the changes in surface productivity dominate over remineralization.

Decreased nutrient uptake by phytoplankton would imply that primary production also decreased. Kahru et al. (2017) indeed found a significant decreasing trend of the annual maximum monthly average net primary production (NPP) between 2011 and 2016 of overall $-23 \%$ in a domain of $\pm 25^{\circ}$ longitude around the Prime Meridian and between $52^{\circ} \mathrm{S}$ and $40^{\circ} \mathrm{S}$ based on satellite observations. However, there was no significant trend before 2011. A decrease in NPP in AAIW source water would lead to an increase in amounts of residual nutrients in the surface ocean which are then transported to AAIW via subduction. This hypothesis, however, cannot explain trends in temperature and salinity that are apparent in our datasets.

We revealed a stronger inter-annual variability of $\mathrm{H}_{4} \mathrm{SiO}_{4}$ concentration as compared to the other macronutrients, which was similarly found for the Pacific and Australian SAMW (Ayers and Strutton 2013). The high IAR of $\mathrm{H}_{4} \mathrm{SiO}_{4}$ does not surprise because north of the APF zone, $\mathrm{H}_{4} \mathrm{SiO}_{4}$ shows a stronger horizontal gradient than other macronutrients (nitrate and phosphate) and silicic acid concentration could limit diatom productivity (Laubscher et al. 1993; Conkright et al. 1994). Of all years, 1998 is the year during which nutrient concentrations were particularly low. $\mathrm{H}_{4} \mathrm{SiO}_{4}$ values as low as $6 \mu \mathrm{mol} \mathrm{kg} \mathrm{kg}^{-1}$ were observed which can be limiting to some diatom species and could be related to the intense phytoplankton bloom occurring in the APF zone (Laubscher et al. 1993; Moore and Abbott 2000).

\section{Conclusions}

This study used observational data from the Prime Meridian section to investigate the inter-annual variability of nutrients, dissolved inorganic carbon (DIC), and apparent oxygen utilization (AOU) along with temperature and salinity in the Antarctic Intermediate Water (AAIW) between 1990 and 2014. We found significant positive trends in DIC, nitrate, and AOU, and negative trends in temperature and salinity in the AAIW.

These observations support a scenario of an increase in the upwelling of nutrients in the Antarctic divergence due to the intensification of westerlies linked to a positive trend in SAM. This would go along with an increase in the northward Ekman transport of the cold nutrient-rich surface waters until they get subducted and form AAIW. This suggests that the Atlantic sector has experienced an increased upper-ocean overturning in contrast to the global analysis of DeVries et al. (2017).

Stronger remineralization and a decrease in net primary production (NPP) might have contributed to the biogeochemical changes that we observed. However, the decrease in net primary production (NPP) observed in the AAIW source region that would lead to an increase in amounts of residual nutrients in the surface ocean could have contributed to the trends we observed in nitrate only since 2011. As this would not alter hydrographic properties, it cannot be the sole explanation.

We suggest that about $75 \%$ of the increase in DIC could be explained by the increase in anthropogenic carbon uptake in the source waters of the AAIW and $25 \%$ due to circulation and potentially production changes. Further studies and longer time series are needed to shed light on the relative contribution of these two mechanisms to the observed changes.

The changes we observed in the AAIW have the potential to significantly impact downstream low latitude primary productivity and carbon cycle over long timescales (Sarmiento et al. 2004; Ayers and Strutton 2013).

Acknowledgements Nutrient data for the 2014 cruise were collected and made available by the Southern Ocean Carbon and Climate Observations and Modeling (SOCCOM) Project funded by National Science Foundation, Division of Polar Programs (NSF PLR -1425989) https://cchdo.ucsd.edu/cruise/06AQ20141202. We gratefully acknowledge the physical oceanographers from AWI for allowing the use of the hydrographic data of cruise ANT-XXX/2 (2014), in particular Olaf Boebel (chief scientist) and Gerd Rohardt. Many thanks to the 
captain and crew and all the data originators. Partial support to JMSC and MGD was received from EU FP7 project CARBOCHANGE (Grant agreement No. 264879) for the participation in the PS89 ANT$\mathrm{XXX} / 2$ cruise. EP and JH were funded by the Helmholtz PostDoc Porgramme PD-102 (Initiative and Networking Fund of the Helmholtz Association).

Open Access This article is distributed under the terms of the Creative Commons Attribution 4.0 International License (http://creativecommons.org/licenses/by/4.0/), which permits unrestricted use, distribution, and reproduction in any medium, provided you give appropriate credit to the original author(s) and the source, provide a link to the Creative Commons license, and indicate if changes were made.

\section{References}

Álvarez M, Tanhua T, Brix H, Lo Monaco C, Metzl N, McDonagh EL, Bryden HL (2011) Decadal biogeochemical changes in the subtropical Indian Ocean associated with Subantarctic Mode Water. J Geophys Res 116:C09016. https://doi.org/10.1029/2010JC006475

Anderson LA, Sarmiento JL (1994) Redfield ratios of remineralization determined by nutrient data analysis. Glob Biogeochem Cycles 8(1):65-80

Aoki S, Yoritaka M, Masuyama A (2003) Multidecadal warming of subsurface temperature in the Indian sector of the Southern Ocean. J Geophys Res 108:8081. https://doi.org/10.1029/ 2000JC000307, C4

Ayers JM, Strutton PG (2013) Nutrient variability in subantarctic mode waters forced by the southern annular mode and ENSO. Geophys Res Lett 40(13):3419-3423. https://doi.org/10.1002/grl.50638

Boebel O (ed) (2015) The expedition PS89 of the research vessel POLARSTERN to the Weddell Sea in 2014/2015. Berichte zur Polar- und Meeresforschung $=$ Reports on polar and marine research. Alfred-Wegener-Institut, Bremerhaven, Germany. https:// doi.org/10.2312/BzPM_0689_2015

Bryden HL, Longworth HR, Cunningham SA (2005) Slowing of the Atlantic meridional overturning circulation at $25^{\circ} \mathrm{N}$. Nature 438(7068):655-657. https://doi.org/10.1038/nature04385

Carpenter JH (1965) The accuracy of the Winkler method for dissolved oxygen analysis. Limnol Oceanogr 10(1):135-140. https://doi.org/10.4319/lo.1965.10.1.0135

Chipman DW, Takahashi T, Breger D, Sutherland SC, Kozyr A, Gaslightwala AF (1994) Carbon dioxide, hydrographic, and chemical data obtained during the $\mathrm{R} / \mathrm{V}$ Meteor cruise 11/5 in the South Atlantic and Northern Weddell Sea areas (WOCE sections A-12 and A-21). Tech. rep., Oak Ridge National Lab., TN (United States). Carbon Dioxide Information Analysis Center; Columbia Univ., Palisades. Lamont-Doherty Earth Observatory. https://doi.org/10.2172/10191502

Conkright ME, Levitus S, Boyer TP (1994) World Ocean Atlas: 1994 Volume 1 Nutrients, U.S. Department of Commerce, NOAA, Washington DC, U.S.A.

De Baar HJW, Buma AGJ, Nolting RF, Cadée GC, Jacques G, Tréguer PJ (1990) On iron limitation of the Southern Ocean: experimental observations in the Weddell and Scotia Seas. Mar Ecol Prog Ser 65:105-122. http://www.jstor.org/stable/24846120

De Baar HJW, Van Leeuwe MA, Scharek R, Goeyens L, Bakker KMJ, Fritsche P (1997) Nutrient anomalies in Fragilariopsis kerguelensis blooms, iron deficiency and the nitrate/phosphate ratio (A. C. Redfield) of the Antarctic Ocean. Deep-Sea Res II Top Stud Oceanogr 44(1):229-260. https://doi.org/10.1016/S09670645(96)00102-6 de las Heras MM, Schlitzer R (1999) On the importance of intermediate water flows for the global ocean overturning. J Geophys Res Oceans 104(C7):15515-15536. https://doi.org/10.1029/ 1999JC900102

DeVries T, Holzer M, Primeau F (2017) Recent increase in oceanic carbon uptake driven by weaker upper-ocean overturning. Nature 542(7640):215-218. https://doi.org/10.1038/nature21068

Dickson AG (2010) Standards for ocean measurements. Oceanography 23(3):34-47. https://doi.org/10.5670/oceanog.2010.22

Downes SM, Budnick AS, Sarmiento JL, Farneti R (2011) Impacts of wind stress on the Antarctic Circumpolar Current fronts and associated subduction. Geophys Res Lett 38:L11605. https://doi.org/10.1029/2011GL047668

Driemel A, Fahrbach E, Rohardt G, Beszczynska-Möller A, Boetius A, Budéus G, Cisewski B, Engbrodt R et al (2017) From pole to pole: 33 years of physical oceanography onboard R/V Polarstern. Earth Syst Sci Data 9:211-220. https://doi.org/10.5194/essd-9-211-2017

Durack PJ, Wijffels SE (2010) Fifty-year trends in global ocean salinities and their relationship to broad-scale warming. J Clim 23(16):4342-4362. https://doi.org/10.1175/2010JCLI3377.1

Gordon AL (1981) South Atlantic thermocline ventilation. Deep-Sea Res A Oceanogr Res Pap 28(11):1239-1264. https://doi.org/10. 1016/0198-0149(81)90033-9

Grasshoff K, Ehrhardt M, Kremling K (1983) Methods of seawater analysis. Verlag Chemie, Weinheim, p 419

Gruber N, Gloor M, Mikaloff Fletcher SE, Doney SC, Dutkiewicz S, Follows MJ, Gerber M, Jacobson AR, Joos F, Lindsay K et al (2009) Oceanic sources, sinks, and transport of atmospheric $\mathrm{CO}_{2}$. Glob Biogeochem Cycles 23(GB1005). https://doi.org/10.1029/ 2008GB003349

Hanawa K, Talley LD (2001) Mode waters. Int Geophys Ser 77:373386. https://doi.org/10.1016/S0074-6142(01)80129-7

Hauck J, Völker C, Wang T, Hoppema M, Losch M, Wolf-Gladrow DA (2013) Seasonally different carbon flux changes in the Southern Ocean in response to the southern annular mode. Glob Biogeochem Cycles 27(4):1236-1245. https://doi.org/10.1002/ 2013GB004600

Hoppema M (2004a) Weddell Sea is a globally significant contributor to deep-sea sequestration of natural carbon dioxide. Deep-Sea Res I Oceanogr Res Pap 51(9):1169-1177. https://doi.org/10.1016/j. dsr.2004.02.011

Hoppema M (2004b) Weddell Sea turned from source to sink for atmospheric $\mathrm{CO}_{2}$ between pre-industrial time and present. Glob Planet Chang 40(3):219-231. https://doi.org/10.1016/j.gloplacha. 2003.08.001

Hoppema M, Fahrbach E, Schröder M, Wisotzki A, De Baar HJW (1995) Winter-summer differences of carbon dioxide and oxygen in the Weddell Sea surface layer. Mar Chem 51(3):177-192. https://doi.org/10. 1016/0304-4203(95)00065-8

Hoppema M, Fahrbach E, Richter KU, De Baar HJW, Kattner G (1998) Enrichment of silicate and $\mathrm{CO}_{2}$ and circulation of the bottom water in the Weddell Sea. Deep-Sea Res I Oceanogr Res Pap 45(11):1797-1817. https://doi.org/10.1016/S0967-0637(98)00029-6

Hoppema M, Bakker K, van Heuven SMAC, van Ooijen JC, De Baar HJW (2015) Distributions, trends and inter-annual variability of nutrients along a repeat section through the Weddell Sea (1996-2011). Mar Chem 177:545-553. https://doi.org/10.1016/j.marchem.2015.08.007

Iida T, Odate T, Fukuchi M (2013) Long-term trends of nutrients and apparent oxygen utilization south of the polar front in Southern Ocean intermediate water from 1965 to 2008. PloS one 8(8):e71,766. https://doi.org/10.1371/journal.pone.0071766

Kahru M, Lee Z, Mitchell BG (2017) Contemporaneous disequilibrium of bio-optical properties in the Southern Ocean. Geophys Res Lett 44:2835-2842. https://doi.org/10.1002/2016GL072453 
Khatiwala S, Primeau F, Hall T (2009) Reconstruction of the history of anthropogenic $\mathrm{CO}_{2}$ concentrations in the ocean. Nature 462(7271):346-349. https://doi.org/10.1038/nature08526

Klatt O, Roether W, Hoppema M, Bulsiewicz K, Fleischmann U, Rodehacke C, Fahrbach E, Weiss RF, Bullister JL (2002) Repeated CFC sections at the Greenwich Meridian in the Weddell Sea. J Geophys Res Oceans 107(C4). https://doi.org/10.1029/ 2000JC000731

Landschützer P, Gruber N, Haumann FA, Rödenbeck C, Bakker DCE, Van Heuven S, Hoppema M, Metzl N, Sweeney C, Takahashi T et al (2015) The reinvigoration of the Southern Ocean carbon sink. Science 349(6253):1221-1224. https://doi.org/10.1126/science. aab2620

Laubscher RK, Perissinotto R, McQuaid CD (1993) Phytoplankton production and biomass at frontal zones in the Atlantic sector of the Southern Ocean. Polar Biol 13(7):471-481

Lauvset SK, Key RM, Olsen A, van Heuven S, Velo A, Lin X, Schirnick C, Kozyr A, Tanhua T, Hoppema M, Jutterström S, Steinfeldt R, Jeansson E, Ishii M, Perez FF, Suzuki T, Watelet $S$ (2016) A new global interior ocean mapped climatology: the $1^{\circ} \times 1^{\circ}$ GLODAP version 2. Earth Syst Sci Data 8:325-340. https://doi.org/10.5194/essd-8-325-2016

Le Quéré C, Rödenbeck C, Buitenhuis ET, Conway TJ, Langenfelds R, Gomez A, Labuschagne C, Ramonet M, Nakazawa T, Metzl $\mathrm{N}$ et al (2007) Saturation of the Southern Ocean $\mathrm{CO}_{2}$ sink due to recent climate change. Science 316(5832):1735-1738. https://doi.org/10.1126/science.1136188

Le Quéré C, Andrew RM, Canadell JG, Sitch S, Korsbakken JI, Peters GP, Manning AC, Boden TA, Tans PP, Houghton RA et al (2016) Global carbon budget 2016. Earth Syst Sci Data 8(2):605-649. https://doi.org/10.5194/essd-8-605-2016

Marinov I, Gnanadesikan A, Toggweiler JR, Sarmiento JL (2006) The Southern Ocean biogeochemical divide. Nature 441(7096):964967. https://doi.org/10.1038/nature04883

Marshall GJ (2003) Trends in the Southern Annular Mode from observations and reanalyses. J Clim 16(24):4134-4143. https://doi.org/ 10.1175/1520-0442(2003)016<4134:TITSAM > 2.0.CO;2

Martin JH, Gordon RM, Fitzwater SE (1990) Iron in Antarctic waters. Nature 345(6271):156-158

Metzl N, Brunet C, Jabaud-Jan A, Poisson A, Schauer B (2006) Summer and winter air-sea $\mathrm{CO}_{2}$ fluxes in the Southern Ocean. Deep-Sea Res I Oceanogr Res Pap 53(9):1548-1563. https://doi. org/10.1016/j.dsr.2006.07.006

Mintrop L, Pérez FF, González-Dávila M, Santana-Casiano JM, Körtzinger A (2000) Alkalinity determination by potentiometry: intercalibration using three different methods. Ciencias Marinas 26(1):23-37

Mitchell BG, Brody EA, Holm-Hansen O, McClain C, Bishop J (1991) Light limitation of phytoplankton biomass and macronutrient utilization in the Southern Ocean. Limnol Oceanogr 36(8):16621677. https://doi.org/10.4319/lo.1991.36.8.1662

Moore JK, Abbott MR (2000) Phytoplankton chlorophyll distributions and primary production in the Southern Ocean. J Geophys Res 105(C12):28709-28722. https://doi.org/10.1029/1999JC000043

Morrison AK, Frölicher TL, Sarmiento JL (2015) Upwelling in the Southern Ocean. Phys Today 68(1):27-32. https://doi.org/10. 1063/PT.3.2654

Nelson DM, Smith W (1991) Sverdrup revisited: critical depths, maximum chlorophyll levels, and the control of Southern Ocean productivity by the irradiance-mixing regime. Limnol Oceanogr 36(8):1650-1661. https://doi.org/10.4319/lo.1991.36.8.1650

Olsen A, Key RM, van Heuven S, Lauvset SK, Velo A, Lin X, Schirnick C, Kozyr A, Tanhua T, Hoppema M, Jutterström S, Steinfeldt R, Jeansson E, Ishii M, Pérez FF, Suzuki T (2016) The Global Ocean Data Analysis Project version 2 (GLODAPv2) —an internally consistent data product for the world ocean. Earth Syst Sci Data 8:297-323. https://doi.org/10.5194/essd-8-297-2016

Orsi AH, Whitworth T, Nowlin WD (1995) On the meridional extent and fronts of the Antarctic Circumpolar Current. Deep-Sea Res I Oceanogr Res Pap 42(5):641-673. https://doi.org/10.1016/09670637(95)00021-W

Orsi AH, Johnson GC, Bullister JL (1999) Circulation, mixing, and production of Antarctic Bottom Water. Prog Oceanogr 43(1):55109. https://doi.org/10.1016/S0079-6611(99)00004-X

Pardo PC, Tilbrook B, Langlais C, Trull TW, Rintoul SR (2017) Carbon uptake and biogeochemical change in the Southern Ocean, south of Tasmania. Biogeosciences 14(22):5217-5237

Peterson RG, Whitworth T (1989) The Subantarctic and Polar Fronts in relation to deep water masses through the southwestern Atlantic. J Geophys Res Oceans 94(C8):10817-10838. https://doi.org/10.1029/JC094iC08p10817

Redfield AC (1963) The influence of organisms on the composition of seawater. The Sea 2:26-77

Rintoul SR, Hughes CW, Olbers D (2001) The Antarctic circumpolar current system. In: Siedler G, Church J, Gould J (eds). Academic Press, New York, pp 271-302. https://doi.org/10.1016/S00746142(01)80124-8

Sabine CL, Feely RA, Gruber N, Key RM, Lee K, Bullister JL, Wanninkhof R, Wong C, Wallace DW, Tilbrook B et al (2004) The oceanic sink for anthropogenic $\mathrm{CO}_{2}$. Science 305(5682):367-371. https://doi.org/10.1126/science.1097403

Salt LA, van Heuven SMAC, Claus ME, Jones EM, de Baar HJW (2015) Rapid acidification of mode and intermediate waters in the southwestern Atlantic Ocean. Biogeosciences 12(5):1387-1401. https://doi.org/ 10.5194/bg-12-1387-2015

Sarmiento JL, Gruber N, Brzezinski MA, Dunne JP (2004) Highlatitude controls of thermocline nutrients and low latitude biological productivity. Nature 427(6969):56-60. https://doi.org/10.1038/ nature 02127

Skliris N, Marsh R, Josey SA, Good SA, Liu C, Allan RP (2014) Salinity changes in the World Ocean since 1950 in relation to changing surface freshwater fluxes. Climate dynamics 43(34):709-736. https://doi.org/10.1007/s00382-014-2131-7

Sloyan BM, Rintoul SR (2001) Circulation, renewal, and modification of Antarctic Mode and Intermediate Water. J Phys Oceanogr 31(4):1005-1030. https://doi.org/10.1175/1520-0485(2001)031< 1005:CRAMOA > 2.0.CO;2

Talley LD (1996) Antarctic intermediate water in the South Atlantic. In: Wefer G, Berger WH, Siedler G, Webb DJ (eds) The South Atlantic. Springer, Berlin, pp 219-238

Talley LD (2013) Closure of the global overturning circulation through the Indian, Pacific, and Southern Oceans: schematics and transports. Oceanography 26(1):80-97

Tanhua T, Hoppema M, Jones EM, Stöven T, Hauck J, González Dávila M, Santana-Casiano M, Álvarez M, Strass VH (2017) Temporal changes in ventilation and the carbonate system in the Atlantic sector of the Southern Ocean. Deep-Sea Res II Top Stud Oceanogr 138:26-38. https://doi.org/10.1016/j.dsr2.2016. 10.004

Thompson DW, Solomon S, Kushner PJ, England MH, Grise KM, Karoly DJ (2011) Signatures of the Antarctic ozone hole in Southern Hemisphere surface climate change. Nat Geosci 4(11):741-749. https://doi.org/10.1038/NGEO1296

van Heuven SMAC, Hoppema M, Huhn O, Slagter HA, De Baar HJW (2011) Direct observation of increasing $\mathrm{CO}_{2}$ in the Weddell Gyre along the Prime Meridian during 19732008. Deep-Sea Res II Top Stud Oceanogr 58(25):2613-2635. https://doi.org/10.1016/j.dsr2.2011. 08.007

van Heuven SMAC, Hoppema M, Jones EM, de Baar HJW (2014) Rapid invasion of anthropogenic $\mathrm{CO}_{2}$ into the deep circulation of 
the Weddell Gyre. Philos Trans R Soc Lond A: Math Phys Engi Sci 372(2019):20130,056. https://doi.org/10.1098/rsta.2013.0056

Weiss RF (1970) The solubility of nitrogen, oxygen and argon in water and seawater. Deep-Sea Res 17:721-735

Weiss RF, Östlund HG, Craig H (1979) Geochemical studies of the Weddell Sea. Deep Sea Res A Oceanogr Res Pap 26(10):10931120. https://doi.org/10.1016/0198-0149(79)90059-1

Wetzel P, Winguth A, Maier-Reimer E (2005) Sea-to-air $\mathrm{CO}_{2}$ flux from 1948 to 2003: a model study. Global Biogeochem Cycles 19:GB2005. https://doi.org/10.1029/2004GB002339
Whitworth T, Nowlin WD (1987) Water masses and currents of the Southern Ocean at the Greenwich Meridian. J Geophys Res Oceans 92(C6):6462-6476. https://doi.org/10.1029/JC092iC06p 06462

Wunsch C, Heimbach P (2006) Estimated decadal changes in the North Atlantic meridional overturning circulation and heat flux 1993-2004. Journal of Physical Oceanography 36(11):20122024. https://doi.org/10.1175/JPO2957.1

\section{Affiliations}

Essowè Panassa $^{1}$ (D) . J. Magdalena Santana-Casiano ${ }^{2} \cdot$ Melchor González-Dávila $^{2} \cdot$ Mario Hoppema $^{1}$. Steven M.A.C van Heuven ${ }^{3}$. Christoph Völker ${ }^{1}$ - Dieter Wolf-Gladrow ${ }^{1}$. Judith Hauck ${ }^{1}$

J. Magdalena Santana Casiano

magdalena.santana@ulpgc.es

Melchor González-Dávila

melchor.gonzalez@ulpgc.es

Mario Hoppema

mario.hoppema@awi.de

Steven M.A.C van Heuven

svheuven@gmail.com

Christoph Völker

christoph.voelker@awi.de

Dieter Wolf-Gladrow

dieter.wolf-gladrow@awi.de

Judith Hauck

judith.hauck@awi.de

1 Alfred Wegener Institute, Helmholtz Centre for Polar and Marine Research, Am Handelshafen 12, 27570

Bremerhaven, Germany

2 Instituto de Oceanografía y Cambio Global. Universidad de Las Palmas de Gran Canaria, Campus de Tafira, 35017, Las Palmas de Gran Canaria, Spain

3 Royal Netherlands Institute for Sea Research, 1790 AB Den Burg, The Netherlands 